\title{
A Fixed Time Kinetic and Spectrophotometric Method for the Determination of $\left[\mathrm{C}_{16} \mathrm{TAB}\right]$
}

\author{
V. W. Bhagwat, Mona Pipada, Ajit Choube, ${ }^{\dagger}$ S.B. Jonnaladgadda ${ }^{\ddagger}$ and Brijesh Pare ${ }^{s^{*}}$ \\ School of Studies in Chemistry, Iikram Cinversin, Ujain-456010. INDLA \\ IPCA Laboratories, Ratlam, INDLA \\ Chnversitv of Durban-Hestille, Durban, SOUTHAFRICA

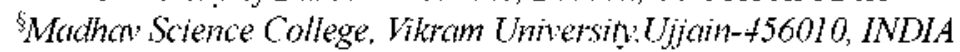 \\ Received April 19, 2002
}

Key Words : Surfactants, $C_{16}$ TAB, Methylene violet. Dye-surfactant interaction

Surfactants are potential anthropogenic pollutants. Surfactants enter waters and wastewaters mainly through the discharge of aqueous waters from household and industrial laundring and other cleaning operations. Ionic surfactants make up about two thirds of the total surfacatnts used. and nonionics about one third. Dye-surfactant interactions have been widely studied by a number of spectrophotometric methods for the determination of surfactants. ${ }^{\text {l.2 }}$ A bathocluromic shift of the absorption maxima is an indication of its interaction in the micellar medium. This is attributed to the localization of the dye in bulk aqueous medium due to electrostatic repulsion of the cationic micellar surface and to increased delocalization of the pi electron in the conjugated bond system. thus leading to a change in the excited energy: states. Methylene violet is a water-soluble dye of phenazine class. ${ }^{3}$ has a sharp absorption peak in visible region and exhibits a bathochromic shift of $20 \mathrm{~nm}$ with $\mathrm{C}_{16} \mathrm{TAB}$. Therefore. an analytical method for determining trace amounts of $\mathrm{C}_{16} \mathrm{TAB}$ has been designed. Furthermore, the oxidative depletion of $\mathrm{MV}^{-}$by chloramine- $\mathrm{T}^{4}$ abbreviated as CAT is specifically and selectively catalyzed by $\mathrm{C}_{16} \mathrm{TAB}$. Thus. based on the $\mathrm{MV}^{+}-\mathrm{CAT}$ reaction as an indicator reaction. a fixed time kinetic analytical method for the trace determination of a $\mathrm{C}_{16} \mathrm{TAB}$ is also proposed. whereas the kinetics and mechanism of this reaction are discussed elsewhere. ${ }^{5}$

\section{Experimental Section}

The chemicals used were of high purity (Aldrich. B.D.H.). and double distilled water was used throughout to prepare the solutions.

1) Chloramine-T solution. A stock solution of $1.0 \times 10^{-2}=$ mol dm ${ }^{-3} \mathrm{CAT}$ (E. Merck) was prepared by dissolving 0.2817 $\mathrm{g}$ in $100 \mathrm{~mL}$ of water

2) Methylene Violet solution. A stock solution of $1.0 \times 10^{-3}$ mol $\mathrm{dm}^{-3} \mathrm{MV}^{-}$was prepared by dissolving $0.0379 \mathrm{~g}$ of

\footnotetext{
Corresponding Author. E-mail: brijesh pareahotmail.com
}

methylene violet (Aldrich) in $100 \mathrm{~mL}$ water. Working solutions were prepared by appropriate dilution of the stock solution.

3) $\mathrm{C}_{16} \mathrm{TAB}$. The $100 \mathrm{~mL}$ stock solution of $1.0 \times 10^{-1} \mathrm{~mol}$ $\mathrm{dm}^{-3}$ the detergent $(\mathrm{BDH})$ was prepared by dissolving $0.0364 \mathrm{~g}$ of $\mathrm{C}_{16} \mathrm{TAB}$ in $50 \%$ acetic acid (v/v).

4) Perchloric acid. A stock solution of $1.0 \times 10^{-1} \mathrm{~mol} \mathrm{dm}^{-3}$ $\mathrm{HClO}_{4}$ was prepared by diluting the previously standardized acid.

Kinetic Procedure. In all the experiments the pseudofirst-order kinetics with respect to methylene violet were monitored at $560 \mathrm{~nm}$. using a systronix UV-VIS spectrophotometer. Beer's law was valid for the measurement under the experimental conditions considered. No interference from the reagents. intermediates or products was observed at $560 \mathrm{~nm}$. The total initial volume of the reaction mixture was $10 \mathrm{~mL}$ at $\left(25.0 \pm 0.1^{\circ} \mathrm{C}\right)$. In all the experiments. the reactions were monitored up to two half lives. Constant ionic strength of the reaction mixture was maintained by adding the required amount of sodium sulphate solution.

$$
\begin{aligned}
\mathrm{MV}^{-} & +4 \mathrm{ArSO}_{2} \mathrm{NHCl}+4 \mathrm{H}_{2} \mathrm{O}=\mathrm{P}^{+}+4 \mathrm{ArSO}_{2} \mathrm{NH}_{2} \\
& +\mathrm{CH}_{3} \mathrm{CN}+2 \mathrm{CH}_{3} \mathrm{CH}_{2} \mathrm{OH}+4 \mathrm{HCl}
\end{aligned}
$$

$\mathrm{P}^{+}=7$-amino-9-phenyl quinoxaline-2.3-dicarboxylic acid. ${ }^{5}$

\section{Results and Discussion}

The addition of $\mathrm{C}_{16} \mathrm{TAB}$ to the dye solution shifts its absorbance maxima from $560 \mathrm{~nm}$ to $580 \mathrm{~nm}$ (Figure 1). The calibration curve [Table 1] exhibits linearity for the range of $1.0 \times 10^{-4} \mathrm{~mol} \mathrm{dm}^{-3}$ to $7.0 \times 10^{-4} \mathrm{~mol} \mathrm{dm}^{-3}$. Beyrond this range linearity was not obtained. This is obviously because of the fact that the $\mathrm{MV}^{+}$-surfactant interactive species is solublized near the critical micelle concentration $(\mathrm{cmc})$ of the detergent. The reported cme of $\mathrm{C}_{16} \mathrm{TAB}$ is $9.1 \times 10^{-4} \mathrm{~mol} \mathrm{dm}^{-3}$.

Scope as kinetic-catalytic indicator reaction. To find a still lower limit of determination, and considering the substantial catalytic effect [Table 2] of $\mathrm{C}_{16} \mathrm{TAB}$ on the $\mathrm{MV}^{-}$CAT reaction. a fixed time method was tested. The scope of the title reaction as the catalytic indicator reaction was very 


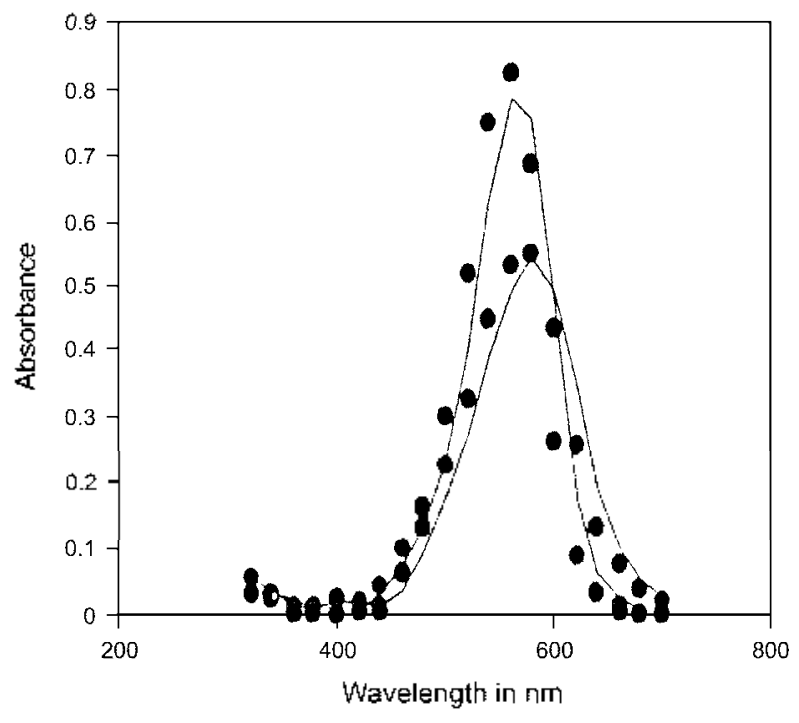

Figure 1. Repetitive Scan and shifting of absorbance maxima.

Table 1. Dye-surfactant interaction $\left(\left[\mathrm{MV}^{+}\right]=1.0 \times 10^{-5} \mathrm{~mol} \mathrm{dm^{-3 }}\right.$; Temperature $25^{\circ} \mathrm{C}$ )

\begin{tabular}{cc}
\hline$[\mathrm{CTAB}] / 10^{-4} \mathrm{~mol} \mathrm{dm}^{-3}$ & Absorbance* $^{*}$ \\
\hline Nil & 0.512 \\
1.0 & 0.620 \\
2.0 & 0.634 \\
3.0 & 0.645 \\
4.0 & 0.630 \\
5.0 & 0.663 \\
6.0 & 0.678 \\
7.0 & 0.683 \\
\hline
\end{tabular}

* Mean of duplicate experiments.

Table 2. C ${ }_{15}$ TAB Catalyzed Reaction $\left(\left[\mathrm{MV}^{+}\right] 2.0 \times 10^{-4} \mathrm{~mol} \mathrm{dm}^{-3}\right.$; $\left[\mathrm{H}^{-}\right] 2.0 \times 10^{-2} \mathrm{~mol} \mathrm{dm}-3$; [chloramine-T] $2.0 \times 10^{-4} \mathrm{~mol} \mathrm{dm} \mathrm{dm}^{-3}$; Temperature $25^{\circ} \mathrm{C}$ )

\begin{tabular}{cc}
\hline$\left[\mathrm{C}_{1 \mathrm{~s}} \mathrm{TAB}\right] \times 10^{-5} \mathrm{~mol} \mathrm{dm}^{-3}$ & ${ }^{*} \mathrm{k}_{0}{ }^{0} \times 10^{-2} \mathrm{~s}^{-1}$ \\
\hline Nil & 2.35 \\
1.0 & 3.15 \\
2.0 & 6.35 \\
3.0 & 9.36 \\
4.0 & 12.70 \\
5.0 & 18.11 \\
6.0 & 20.70 \\
\hline
\end{tabular}

* Mean of duplicate runs.

promising. In this fixed time method the lowest determination limit fell to the $5.0 \times 10^{-6} \mathrm{~mol} \mathrm{dm}{ }^{-3}$ range. The plot of $\log \mathrm{Abs}$ (for a fixed time) versus $\left[\mathrm{C}_{16} \mathrm{TAB}\right]$ yields a good straight line. Reagent solutions were mixed in the order of $2.0 \mathrm{~mL}$ each of methylene violet and perchloric acid. Water. bringing the total volume to $10.0 \mathrm{~mL}$. plus catalyst or other reagents were used when necessary: A separately thermostatted solution of CAT $2.0 \mathrm{~mL}$ was added to commence the reaction. After vigorous mixing the solution was transferred to a spectrophotometer cell. A fixed time procedure was
Table 3. Absorbance values of methylene violet at fixed time for $\left[\mathrm{C}_{10} \mathrm{TAB}\right]$ variation $\left(\mathrm{MV}^{+}\right]=2.0 \times 10^{-5} \mathrm{~mol} \mathrm{\textrm {dm } ^ { - 3 }} ;\left[\mathrm{H}^{-}\right]=1.0 \times 10^{-2}$ mol dm${ }^{-3}:$ [CAT] $=2.0 \times 10^{-4} \mathrm{~mol} \mathrm{dm}^{-3}$ : Temperature $25^{\circ} \mathrm{C}$ )

\begin{tabular}{cc}
\hline$[\mathrm{CTAB}] / 10^{-5} \mathrm{~mol} \mathrm{dm}^{-3}$ & $\begin{array}{c}\text { Absorbance* } \\
300 \mathrm{~s}\end{array}$ \\
\hline- & $0.784^{* *}$ \\
0.05 & 0.762 \\
0.07 & 0.729 \\
0.09 & 0.671 \\
1.0 & 0.687 \\
2.0 & 0.551 \\
3.0 & 0.462 \\
4.0 & 0.325 \\
5.0 & 0.276 \\
6.0 & 0.207 \\
\hline
\end{tabular}

*Mean of triplicate runs. **Not taken for plot.

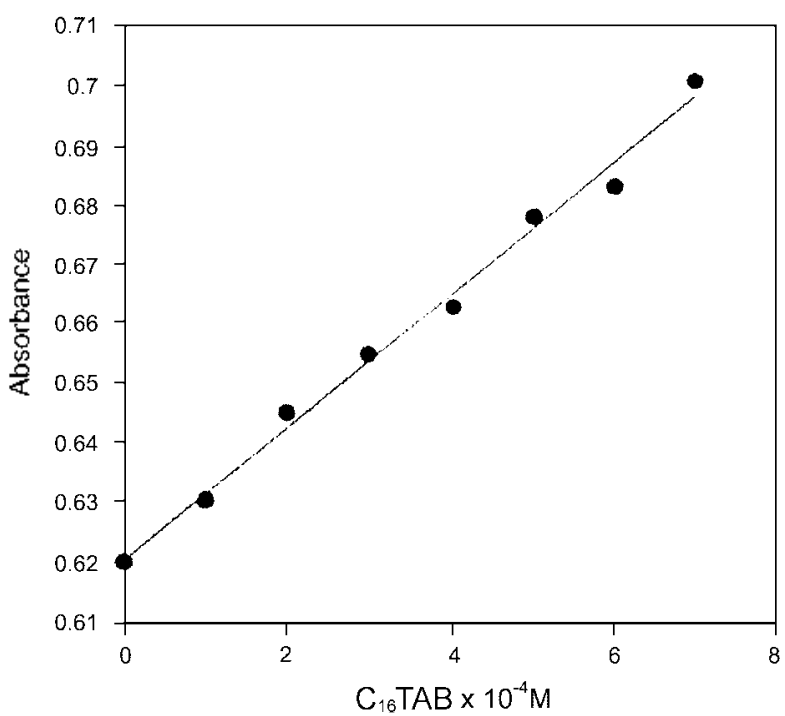

Figure 2. Calibration curve, direct complexation.

Table 4. Tolerance ratio of Interferents $\left(\left[\mathrm{MV}^{+}\right] 2.0 \times 10^{-5} \mathrm{~mol} \mathrm{dm}{ }^{-3}\right.$. $\left[\mathrm{H}^{+}\right] 2.0 \times 10^{-2} \mathrm{~mol} \mathrm{dm}{ }^{-3}$, [chloramine-T] $2.0 \times 10^{-4} \mathrm{~mol} \mathrm{dm}$; Temperature $25^{\circ} \mathrm{C}$ )

\begin{tabular}{lc}
\hline Cation & Tolerance ratio \\
\hline W(VI), Ce(IV), Se(IV) & $10000^{*}$ \\
Ca(II ), Ba(II), Ru(III), Os(VIII) & 1000 \\
Ni(II $), \mathrm{Co}(\mathrm{II}), \mathrm{Mn}(\mathrm{II}), \mathrm{Fe}(\mathrm{III}), \mathrm{Cu}(\mathrm{II}), \mathrm{Pd}(\mathrm{II})$ & 100 \\
\hline
\end{tabular}

Maximum ratio tested.

used to plot the calibration curves. Kinetic runs were carried out at $\left(25.0 \pm 0.1^{\circ} \mathrm{C}\right)$ in duplicate with fixed initial concentrations of $\mathrm{MV}^{+}=2.0 \times 10^{-5} \mathrm{~mol} \mathrm{dm} \mathrm{dm}^{-3} . \mathrm{H}^{+}=2.0 \times 10^{-2} \mathrm{~mol}$ $\mathrm{dm}^{-3}$ and $\mathrm{CAT}=2.0 \times 10^{-4} \mathrm{~mol} \mathrm{dm} \mathrm{m}^{-3}$ and varied concentrations of $\mathrm{C}_{16 \mathrm{TAB}}$ in the range of $1.0 \times 10^{-5}$ to $6.0 \times 10^{-5} \mathrm{~mol} \mathrm{dm}^{-3}$. The absorbance at $580 \mathrm{~nm}$ was measured at the fixed time of $300 \mathrm{~s}$ (Table 3). Figure 2 illustrates the $\log \mathrm{Abs}$ at $300 \mathrm{~s}$ versus $\left[\mathrm{C}_{16} \mathrm{TAB}\right]$. which is a good straight line with $\mathrm{r}^{2}=$ 0.998.

Interference studies. In the direct complexation method there was no interference of anions. such as clloride. 
bromide iodide and nitrite. but the kinetic method suffers with the interferences of these ions. Sublation is required. therefore to get rid of the non-surfactant impurities. The addition of various cations did not interfere in either case. The presence of sodium dodecylsulfate an anionic surfactant. did not cause interference in the direct interaction. nor did it exhibit any catalytic effect on the oxidation reaction in the chosen range. The effects of the presence of various potential interfering cations were investigated. Synthetic mixtures containing various concentrations of numerous individual metal cations and $\left[\mathrm{C}_{16} \mathrm{TAB}\right] 1.0 \times 10^{-5} \mathrm{~mol} \mathrm{dm}^{-3}$ were prepared. None of the cations tested interference. Table 4 summarizes the tolerance ratios for the presence of each individual species. The analytical results summarized in Table 4, clearly show that the proposed kinetic-catalytic methods have far higher tolerance limits.

\section{Conclusion}

The $\mathrm{C}_{16} \mathrm{TAB}$ catalyzed oxidation of methylene violet by acidic chloramine-T reaction can be effectively used to determine cationic detergent as low as $0.73 \mathrm{mg} / \mathrm{L}$ to 6.06 $\mathrm{mg} / \mathrm{L}$. Non-surfactant impurities can be easily removed from the real sample by sublation. The direct interaction of the dye and the detergent provides a calibration curve with which $\mathrm{C}_{16} \mathrm{TAB}$ can be determined in waste water after sublation up to as low as $36 \mathrm{mg} / \mathrm{L}$. Most of the other cations studied had negligible influence on $\mathrm{C}_{16} \mathrm{TAB}$ determination.

\section{References}

1. Linado. R. A.: Neubecker. I. A. Anal. Chem 1983. 55.93R.

2. Zyka. I. Instrumentation in Analytical Chemistry: Ellis Horwood Limited: West sussex. England, 1994; Vol 2, pp 309-325.

3. Elderfield. R. C. Heteroctchic Compomds: John Wiley \& Sons: New York. 1957; Vol 6.

4. Venlkatesha. B. M.: Ananda. S.: Mahadevappa. D. S. Iht. J. Chem. Kinet. 1995. 27.663.

5. Bhagwat. V. W.: Pipada. M.: Ionnalagadda. S. B.: Pare. B. Indian J. of Chem. 2002. accepted.

6. Fendler. J. H.: Fendler. E. J. Catahsis in Micellar and Macronolecular Stutents: Academic press: New York. 1975. 